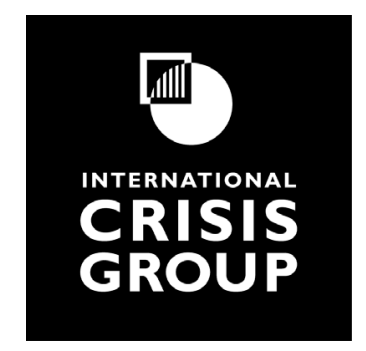

\title{
The Long Haul Ahead for Myanmar's Rohingya Refugee Crisis
}

Asia Report №296 | 16 May 2018 


\section{Table of Contents}

Executive Summary .......................................................................................... i

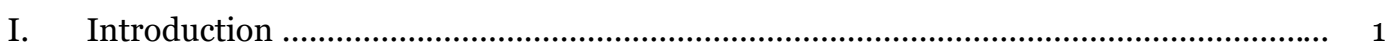

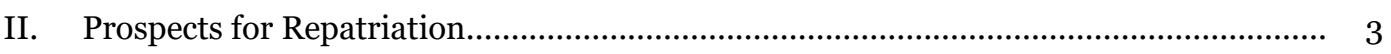

III. Situation in the Bangladesh Camps ................................................................ 6

A. Leadership and Governance in the Camps ...................................................... 6

B. Refugee Views on ARSA and the Use of Violence ........................................... 9

IV. What Next for the Crisis? .......................................................................... 11

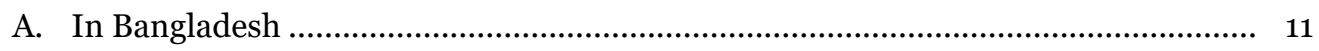

B. In Northern Rakhine State ....................................................................... 13

V. Role of the International Community ............................................................... 15

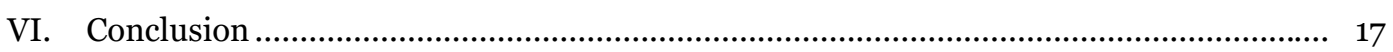

APPENDICES

A. Map of Myanmar ....................................................................................... 18

B. About the International Crisis Group .................................................................. 19

C. Crisis Group Reports and Briefings on Asia since 2015........................................... 20

D. Crisis Group Board of Trustees .......................................................................... 21 


\section{Principal Findings}

What's new? Since August 2017, nearly 700,000 Rohingya have fled Myanmar's brutal military operations in Rakhine State to Bangladesh, joining tens of thousands who left earlier in 2017. The two countries have set a framework for repatriation, but returns are unlikely any time soon. Indeed, small numbers of Rohingya continue to flee.

Why does it matter? Failing to develop long-term strategies for the refugees poses the risk that hundreds of thousands of Rohingya will live in limbo or that Bangladeshi sentiment will turn against them. Authorities might attempt to force return to Myanmar or resettlement elsewhere, which could prompt violence on either side of the border.

What should be done? The Myanmar government must allow the UN and its partners access to northern Rakhine and ease security and other restrictions on the population. In Bangladesh, donors should continue humanitarian aid, while investing in the development of Cox's Bazar district, which hosts the refugees, to improve prospects for their future integration. 


\section{Executive Summary}

In the last eight months, nearly 700,000 Rohingya have fled indiscriminate and brutal operations by Myanmar's military in northern Rakhine State to Bangladesh, joining tens of thousands who left earlier in 2017, and many more from previous years. The two countries have agreed upon a procedural framework for voluntary repatriation, but no Rohingya have returned and small numbers continue to flee. The burden of the crisis may have shifted to Bangladesh, but the onus of responsibility remains squarely on Myanmar. The world must pursue accountability for crimes committed and press the government to create the conditions for voluntary repatriation. The tragic reality, however, is that the vast majority of refugees are unlikely to return in the foreseeable future, however much international opprobrium Myanmar faces. Planning for the refugees should proceed on that assumption, while efforts continue to protect those Rohingya who remain in Myanmar.

Failing to develop long-term plans for the refugees would not only risk that hundreds of thousands of people remain in limbo. It could also lead the status quo to morph in dangerous ways. For now, host communities and political elites in Bangladesh largely sympathise with the refugees, but if the sentiments of either were to shift - after the December elections, for example, or due to prolonged negative impacts on host communities - the Rohingya might face pressure to return against their will or move into more isolated camps in Bangladesh, such as those the Bangladeshi government is building on remote Bhasan island. Such developments could prompt instability or violence on either side of the border - due to organised resistance by refugees to relocation or premature repatriation, communal violence against returning refugees, or renewed ARSA mobilisation in Rakhine State.

The social, political and strategic implications of this crisis for Bangladesh are complex at all levels. The host communities - neglected by Dhaka at the best of times - are already feeling the strain. While there is no disagreement in political and policy circles about the intractability of the crisis, there is widespread reluctance to acknowledge it, as it would reflect badly on the Bangladeshi government's ability to protect its sovereignty and could be interpreted as tacit acceptance of ethnic cleansing. Public sympathy for the Rohingya will not last forever, and the current situation is likely to evolve in unpredictable ways. After the December elections, the next government (likely to be the same as the present one) will have to make some difficult longer-term decisions. This subject will be covered in detail in a forthcoming report.

Myanmar has constructed some of the infrastructure that could support a limited return, in the form of heavily guarded processing and holding camps. But it has done little if anything to create conditions on the ground that would give refugees, who fled abuses that likely constitute crimes against humanity, and who continue to be fearful and traumatised, the confidence to go back. It has bulldozed many burned Rohingya villages, is building new roads, power lines and security infrastructure across northern Rakhine State, and has promoted or allowed the expansion of existing villages and construction of new settlements inhabited by other ethnicities. The refugees' return to their homes and lands thus is not only increasingly unlikely, but also becoming impossible in practice. Ethnic Rakhine political leaders and local 
communities are staunchly opposed to repatriation, and the government has done little to mitigate their resistance (indeed, its own relations with ethnic Rakhine have soured). Moreover, hostility toward the Rohingya across Myanmar political elites and in society more broadly remains firmly entrenched.

Most refugees express no intention to go to third countries, and in any case their opportunities to do so are likely to remain scarce. They want to return home. Many refugees hope that the unprecedented international attention their plight has received over the past months could help them achieve that, but they are resigned to staying for an extended period in Bangladesh.

The Arakan Rohingya Salvation Army militant group has significant networks of members and supporters in the Bangladesh camps, and appears determined to remain relevant as an insurgent and political force. The extent to which it can do so is uncertain. It launched a small cross-border attack on a Myanmar army convoy on 5 January, but it has conducted no actions since then. Whether it can leverage widespread disaffection and the significant sympathy it still enjoys in the camps into political authority and sustain cross-border attacks remains to be seen. There is no evidence it has established links to transnational groups like ISIS or al-Qaeda. Indeed, viewing the situation in the camps through a counter-terrorism lens would be unhelpful, as the Bangladeshi authorities appear to recognise.

Improving the situation in northern Rakhine State, where 100,000-150,000 Rohingya still live (and on some estimates as many as 250,000), is not primarily a development challenge. It depends on the Myanmar government and security forces changing course. For the Rohingya in northern Rakhine, particularly those in rural areas, life is becoming increasingly untenable. Curfews, checkpoints and movement restrictions mean that they cannot gain access to farms, fishing grounds, markets, day labour opportunities or social services. These people say they do not want to leave, but if the restrictions are not urgently eased, many may decide they have no other choice.

To prevent further deterioration, the international community should continue pushing the government to allow unfettered United Nations and aid agency access to northern Rakhine. They should press for accountability for crimes committed by the security forces and others. It is also vital to ensure that the government changes conditions in northern Rakhine, to improve the prospects of an eventual refugee return, and more urgently to stabilise the situation of the Rohingya who remain, so as to prevent a further exodus. The recent appointment of a UN special envoy for Myanmar, combined with continued scrutiny and engagement from the Security Council - which just completed a visit to Bangladesh and Myanmar - can hopefully result in some progress on these issues. The recent statement from State Counsellor Aung San Suu Kyi's office promising improved relations with the UN, together with the appointment of a new president, may open space for changes in the government's approach.

Realistically, however, the hundreds of thousands of Rohingya who have fled to Bangladesh appear unlikely to return any time soon. Donors should prepare for the long haul. They should not only fund the humanitarian operation but also invest in the development of Cox's Bazar district, where the refugees currently reside, to reduce the burden on host communities, minimise risks that local sentiment turns against refugees and create an environment more amenable to their integration. The 
Bangladeshi government currently resists such an approach, given the domestic political costs of acknowledging that the Rohingya will remain indefinitely. Similarly, many Western governments are understandably loath to acknowledge explicitly that prospects of the refugees' return are slim. But sustained political discussions on longterm solutions between the government, donors and multilateral institutions are vital. Failing to develop plans for the Rohingya's prolonged stay in Bangladesh risks worsening their suffering and propelling the crisis in a still more dangerous direction.

Brussels, 16 May 2018 


\section{The Long Haul Ahead for Myanmar's Rohingya Refugee Crisis}

\section{Introduction}

Myanmar's Rakhine State has long been afflicted by a toxic mixture of centre-periphery tensions, communal and religious conflict, and extreme poverty and underdevelopment. ${ }^{1}$ In 2014, Crisis Group warned that the state's turmoil represented "a significant threat to the overall success of the country's transition" away from military rule. ${ }^{2}$ Muslims in Rakhine, particularly the Rohingya, have long been subject to state-sponsored discrimination and denial of rights, considered by Amnesty International to amount to apartheid, a crime against humanity. ${ }^{3}$

The Arakan Rohingya Salvation Army (ARSA) militant group, which also refers to itself as Harakah al-Yaqin (Faith Movement), emerged in the wake of communal strife in 2012. It launched attacks on security posts in northern Rakhine in October 2016 and August 2017. These attacks provoked an indiscriminate military response that the United Nations, foreign governments and human rights organisations have branded as ethnic cleansing, likely involving crimes against humanity and possibly genocide. Nearly 700,000 Rohingya have fled to Bangladesh since 25 August 2017. ${ }^{4}$

This report assesses the political and conflict dynamics at play in the refugee camps in Bangladesh and in Rakhine State, looks at how the crisis may evolve, and examines what options the Myanmar government and international community have for addressing it. It is based on research in Myanmar and Bangladesh since November 2017, including interviews with diplomats and aid agency representatives; ARSA members; and more than 100 Rohingya refugees - women and men, educated and

\footnotetext{
${ }^{1}$ For detailed background on Rakhine State, see Crisis Group Asia Reports $\mathrm{N}^{\circ} \mathrm{s} 292$, Myanmar's Rohingya Crisis Enters a Dangerous New Phase, 7 December 2017; 283, Myanmar: A New Muslim Insurgency in Rakhine State, 15 December 2016; 261, Myanmar: The Politics of Rakhine State, 22 October 2014; and 251, The Dark Side of Transition: Violence Against Muslims in Myanmar, 1 October 2013. For other recent Crisis Group reporting on Myanmar, see Asia Briefings $\mathrm{N}^{\circ} \mathrm{s} 149$, Myanmar's Peace Process: Getting to a Political Dialogue, 19 October 2016; 147, The Myanmar Elections: Results and Implications, 9 December 2015; also Asia Reports $\mathrm{N}^{\circ} \mathrm{s} 290$, Buddhism and State Power in Myanmar, 5 September 2017; 287, Building Critical Mass for Peace in Myanmar, 29 June 2017; and 282, Myanmar's New Government: Finding Its Feet?, 29 July 2016.

${ }^{2}$ Crisis Group Report, The Politics of Rakhine State, op. cit., p. i. Rakhine State, in the west of Myanmar, is one of the poorest parts of the country. The extreme poverty is inseparable from antiMuslim discrimination, both by society and by government, through abusive regulations or bureaucratic procedures and practices. The state's population of 3.2 million (2014 census) is made up of a majority of Rakhine Buddhists (around 6o per cent) and a significant minority of Muslims (around 35 per cent). In northern parts of the state, prior to the recent exodus there was a large majority of Muslims. There are also a number of smaller minority groups in Rakhine, including Chin, Mro, Khami, Dainet, Maramagyi and Kaman.

3 “'Caged without a roof': Apartheid in Myanmar's Rakhine State”, Amnesty International, November 2017.

${ }^{4}$ Inter Sector Coordination Group Situation Report: Rohingya Refugee Crisis, Cox’s Bazar, 26 April 2018.
} 
uneducated - in the Bangladesh camps, conducted by experienced personnel fluent in the Rohingya language. Some interviews were also conducted with Rohingya still living in northern Rakhine; these were carried out remotely due to access restrictions and the need to minimise risks to interviewees. The report examines the situation in northern Rakhine State, the prospects for refugees' repatriation and conditions in the Bangladesh camps, including the status of ARSA. A forthcoming report will explore the challenges Bangladesh faces as a result of this sudden, massive influx of refugees, including in relation to the December 2018 Bangladeshi elections. 


\section{Prospects for Repatriation}

The Myanmar and Bangladeshi governments have agreed upon a procedural framework for refugee return, which was supposed to have started on 23 January and be completed "preferably within two years". ${ }^{5}$ But the situation in Rakhine State is not conducive to repatriation and no refugee has returned through formal channels. This is unlikely to change in the short or medium term, and indeed Rohingya continue to leave Rakhine for Bangladesh. Nor does forced repatriation appear likely in the coming months, given the Bangladeshi government's calculation (discussed in section IV.A below) that such a step would be detrimental to its interests in the December elections and in securing donor backing for the huge humanitarian operation that supports the camps. The Awami League government has expressed sympathy for the Rohingya refugees in its campaign materials.

The lack of returns has become the subject of diplomatic manoeuvring by both Myanmar and Bangladesh. Myanmar has repeatedly declared that the physical infrastructure required for repatriation is in place, and that it is not responsible for any delay. ${ }^{6}$ But, as UN High Commissioner for Refugees (UNHCR) Filippo Grandi told the UN Security Council on 13 January, "the construction of infrastructure to support the logistics of return should not be confused with the establishment of conditions conducive to voluntary repatriation". 7 UNHCR and most other UN agencies have had no access to northern Rakhine State since the start of the latest crisis in August 2017, though the government is holding discussions with UNHCR and the UN Development Program, and has recently signalled following the UN Security Council visit that it is open to closer cooperation with the UN (see section $\mathrm{V}$ below).

Bangladesh has reiterated its commitment to voluntary repatriation - that it will not force any Rohingya to return against their will - but has sought to test Myanmar's willingness to accept returnees. A number of repatriation lists have been announced:

- In late December, Bangladesh suggested it would send an initial list of 100,000 Rohingya to be verified by Myanmar for repatriation. The list was to be drawn from a biometric database of refugees compiled by the Bangladeshi authorities. This database did not include household information, however, making it impossible to produce family-based lists, and the verification proposal was quietly dropped. ${ }^{8}$

- On 15 January, Myanmar provided Bangladesh with a list of 508 Hindus that it wanted included in the first batch of returnees, as well as 750 Muslims whose residence in Myanmar it had verified. There was no indication that any of these

\footnotetext{
${ }^{5}$ The bilateral framework consists of a 23 November 2017 "Arrangement on Return of Displaced Persons from Rakhine State”; 19 December 2017 terms of reference for a “Joint Working Group”; and a 16 January 2018 "Physical Arrangement for Repatriation", including a verification form that prospective returnees must fill out in advance.

${ }^{6}$ For example, "Diplomats, UN officials witness true situation in Rakhine State”, Global New Light of Myanmar [GNLM], 16 February 2018.

7 "Briefing on Myanmar at the United Nations Security Council”, Filippo Grandi, UN High Commissioner for Refugees, 13 February 2018; "Union official: the real Rakhine”, GNLM, 15 March 2018. ${ }^{8}$ Crisis Group interviews, UN officials, Yangon and Dhaka, January 2018. See also “100,ooo Rohingya on first repatriation list”, Dhaka Tribune, 27 December 2017.
} 
people wished to return to Myanmar, and Bangladesh has not proceeded with their repatriation. ${ }^{9}$

口 During the 15-17 February visit of the Myanmar home minister to Dhaka, Bangladesh handed over a list of 1,673 Rohingya families (8,032 individuals) "to start the first phase of repatriation". Myanmar says Bangladesh failed to use the agreedupon form, and omitted key identifying information - including declarations of willingness to voluntarily return - making it impossible to assess the list. Myanmar nevertheless announced in early April that it had verified 675 from the list as eligible for repatriation, although it is unclear if or when these people will return, and they were not asked if they are willing to do so. ${ }^{10}$

The major obstacle to return remains fear. Crisis Group interviews in the last several months with Rohingya in the Bangladesh camps suggest that the vast majority of refugees want to return to their villages in Rakhine State as soon as conditions allow; few expressed a desire to go to third countries or settle permanently in Bangladesh. But the Rohingya are only willing to return if they can do so in safety and with dignity. Many refugees said they had lost everything - homes, land, cattle, businesses and savings, as well as loved ones. They believe now is the time to secure their right to compensation for everything they have lost. They understand it will be difficult to obtain that right, but having no real alternatives, they are resigned to waiting and hoping. ${ }^{11}$

Myanmar has done little to create an environment conducive to return. The inaction begins with the fact that the government and military continue to deny the seriousness of the violence that occurred. Without an acceptance of the past, there can be no meaningful steps to ensure that the abuses will not happen again. The only official acknowledgement of wrongdoing relates to the extrajudicial executions of ten Rohingya men in Inn Din village, though the local Reuters journalists who exposed the case remain in prison facing charges under the Myanmar Official Secrets Act. ${ }^{12}$ In a 19 March speech, the Myanmar Armed Forces' commander-in-chief, Min Aung Hlaing, reinforced the view that the Rohingya are outsiders, saying they "do not have the characteristics or culture in common with the ethnicities of Myanmar". The UN secretary-general expressed shock at these comments. ${ }^{13}$

Rakhine Buddhists and other non-Muslims in the state remain staunchly opposed to any refugee return. Many across Myanmar share such views. A recent legislative

\footnotetext{
${ }^{9}$ Crisis Group interviews, UN officials, Yangon and Dhaka, January 2018. See also "Myanmar says over 1,200 refugees to return from Bangladesh next week”, The Irrawaddy, 16 January 2018.

10 "Union official: the real Rakhine", GNLM, 15 March 2018; "Myanmar to accept over 600 refugees from Bangladesh”, Mizzima, 5 April 2018.

${ }^{11}$ Crisis Group interviews, Rohingya refugees, Bangladesh, November 2017-March 2018. See also

“'I still don't feel safe to go home': Voices of Rohingya refugees”, Oxfam, 18 December 2017.

12 "Tatmadaw investigation team issues statement on findings of discovery of unidentified bodies in Inndin Village cemetery in Maungtaw Township", Naypyitaw, 10 January 2018; "Massacre in Myanmar”, Reuters, 8 February 2018; "Myanmar police witness says searched Reuters reporter's home 'for news"', Reuters, 7 March 2018.

13 "UN chief hits out at Myanmar army leader over comments", AFP, 27 March. The commander-inchief referred to the Rohingya as "Bengalis", a term widely used in Myanmar to imply that they are foreigners from Bangladesh.
} 
debate provides a striking example of the strength of domestic sentiment against repatriation. On 14 March, the lower house debated a motion calling on the government to review its decision to relocate 55 (Muslim) Kaman families from Rakhine State to Yangon. The families are among those who were displaced from towns in southern Rakhine by communal violence in 2012 and have been confined to camps since then. Unlike the Rohingya, the Kaman are a recognised ethnic minority who at least in principle enjoy full citizenship.

Yet during the debate, a representative from the military bloc in the lower house expressed concern that "terrorists can pose as IDPs [internally displaced persons]". ${ }^{14}$ When originally proposing the motion on 5 March, a representative from the opposition Union Solidarity and Development Party compared the relocation to the "spreading of cancer cells". ${ }^{15}$ The motion was eventually defeated, with a government representative pointing out that the Kaman are citizens and as such are entitled to live wherever they want in Myanmar but that the reason for their move to Yangon is that local officials have obstructed their return to their homes in southern Rakhine. Any return of Rohingya refugees, who face much greater bureaucratic and legal obstacles to establishing their citizenship, will face far fiercer opposition given the animosity toward them from a broad section of Myanmar society, local media and elites across the political spectrum.

14 "MPs to discuss motion on reviewing resettlement of 55 households from IDP camps", GNLM, 6 March 2018; "Pyithu Hluttaw debates relocation of IDPs to Yangon”, GNLM, 15 March 2018.

15 "Racist Myanmar MP: 'Ethnic Kaman Muslims are cancer cells”, M-Mediagroup.com, 6 March 2018. 


\section{Situation in the Bangladesh Camps}

The lack of any realistic prospect of repatriation means that the Rohingya refugees will remain in the Bangladesh camps for an extended period. The conditions in those camps are dire, and they are likely to remain so despite a huge and costly international humanitarian operation projected at around $\$ 1.2$ billion per year.

That operation has succeeded in providing emergency food, shelter, water, sanitation, health and protection services to some 900,000 refugees, while tackling diphtheria and measles outbreaks. ${ }^{16}$ Yet the reality is that the camps, the largest and most densely populated refugee settlements in the world, were not planned and are not suitable for habitation. Much of the area is rapidly cleared forest land, vulnerable to landslides and at serious risk from cyclones. Makeshift shelters, water supply points and latrines could be flooded or overwhelmed by monsoon rains that will arrive imminently. A large preparation effort is underway, but it faces fundamental constraints of geography. ${ }^{17}$

Most refugees in the camps have had little time to consider the future. They have been focused on daily survival. Now they are preparing for the rains - many arrived at the tail end of the last monsoon season and are aware of the impending challenges, and there have already been some storms. Most count on international concern translating into real improvements in their prospects for return. A major fear remains the possibility of forced repatriation, which occurred following the 1978 and 19911992 exoduses, exacerbated by the diplomatic manoeuvring between Bangladesh and Myanmar described above. ${ }^{18}$

\section{A. Leadership and Governance in the Camps}

Given the chaos of the 2017 exodus, and the difficult conditions on arrival in Bangladesh, leadership and governance structures among refugees have been somewhat ad hoc. Village populations generally did not arrive in the camps together, and therefore are not living together, prompting the emergence of new geographically based leaderships.

There has long been a system of informal leadership in the Rohingya camps in Bangladesh, known as the majhi (traditional leader) system. This system was established at the time of the last major refugee flight in 1991-1992, but it was bedevilled by corruption and the majhis' abuse of power. In 2007 the majhis were replaced with elected camp committees with a facilitation rather than decision-making role. ${ }^{19}$

In the initial stages of the latest exodus, before the aid operation kicked in, the delivery of assistance was disorganised; refugees living close to main roads received

\footnotetext{
${ }^{16}$ The 900,000 figure includes approximately 700,000 who have arrived since August 2017; several tens of thousands who arrived earlier in 2017; and others who have arrived in recent years.

17 "UN launches 2018 appeal for Rohingya refugees and Bangladeshi host communities", joint UNHCR/International Organisation for Migration press release, 16 March 2018.

${ }^{18}$ Crisis Group interviews, Rohingya refugees, Bangladesh, November 2017-March 2018. For discussion of repatriation following the 1978 and 1992 exoduses, see Crisis Group Report, The Politics of Rakhine State, op. cit., section II.C; “The Rohingya Muslims: Ending a cycle of exodus?”, Human Rights Watch, September 1996.

19 "Rohingya crisis: Situation analysis", ACAPS, November 2017.
} 
goods from well-wishers, whereas those in less accessible areas received little. When the Bangladeshi army took charge of crisis management in mid-September, it instructed refugees to select a majhi for each group of 50-200 households. Those chosen were tasked, among other things, with drawing up family lists that the army used as the basis for food distribution. ${ }^{20}$

These majhis are now the lowest level of political organisation in the camps, the primary dispute resolution mechanism (sometimes supported by committees of elders that they arrange), and the interface between refugees and the Bangladeshi authorities and aid agencies. Above them are two further levels: "head majhis" (representing larger "blocks" within the camps) and "chairmen" (representing entire camps, or sections of larger camps). Since it is often not feasible for authorities to deal individually with the hundreds of majhis, many interactions are at the level of head majhis or chairmen. ${ }^{21}$ All of these leaders are men. While refugees with whom Crisis Group spoke expressed no serious grievances against the majhis, the potential for abuses of power similar to those that blighted the system in the past is clear. ${ }^{22}$

While the majhis have the greatest day-to-day influence over refugees' lives, local Bangladeshi power-holders also have significant clout - including current and former local government officials. Some of these individuals were implicated in the early days of the exodus in allegedly taking money from arriving refugees to allow them to put up shelters on government and forest land, though a number of them have denied the charges as politically motivated. These reported scams were mostly shut down by the Bangladeshi army when it stepped in. Nevertheless, these local powerholders are likely to continue controlling some aspects of the political economy related to the refugees. ${ }^{23}$

The Bangladeshi army and intelligence service have asserted their authority in the camps and environs, through perimeter controls, checkpoints and informants albeit with a focus on major security threats rather than low-level criminality, which is mostly handled by the majhis. The majhis have also organised a system of volunteer night watchmen or sentries, at the request of the army and local magistrates. Sentries are provided with a torch, jacket and baton, with each sentry responsible for a block; they report through the majhis to the army each morning. ${ }^{24}$

ARSA is a significant presence in the camps. That ARSA members and supporters are there is unsurprising, given that the militant group had firmly established itself in Rohingya villages across northern Rakhine. Its members were recruited from and lived in those villages - and fled to the Bangladesh camps with the rest of the popu-

\footnotetext{
${ }^{20}$ Crisis Group interviews, refugees and representatives of humanitarian aid agencies, Bangladesh, November 2017-March 2018.

${ }^{21}$ To give a sense of numbers, in the Balukhali mega-camp which hosts more than half a million refugees, there are over 800 blocks, each represented by a head majhi.

${ }^{22}$ Crisis Group interviews, refugees and representatives of humanitarian aid agencies, Bangladesh, November 2017-March 2018. Due to the risk that majhis may be unrepresentative or corrupt, some aid agencies have established parallel project structures that do not automatically go through the majhis.

${ }^{23}$ Crisis Group interviews, refugees and representatives of humanitarian aid agencies, Bangladesh, November 2017-March 2018. See also “Extortion adds to Rohingyas' woes”, New Age Bangladesh, 26 September 2017.

24 Ibid.
} 
lation. A small number of senior leaders and prominent cadres avoided entering the camps or being biometrically registered by the Bangladeshi authorities. These men stayed out of the camps as a security precaution and to be able to move more freely. ${ }^{25}$

What has been less certain is the extent to which ARSA would be able to regroup in the camps, mobilise the population and project its authority. It was able to do so in Rakhine State by leveraging the anger and desperation of a community facing daily oppression, and by building strong networks through prominent local community and religious leaders. It offered hope, or at least a sense of agency, and bolstered its position via a combination of religious legitimacy and fear. ${ }^{26}$ Mobilising in the Bangladesh camps is a completely different prospect. Village populations are scattered across the camps, new leaders (the majhis) are emerging, and the "common enemies" that ARSA rallied against - the Myanmar security forces - are far away across an international border. When the majority of refugees are struggling to establish basic standards of living in the camps and come to terms with the catastrophe triggered by ARSA's last major action, the militant group's raison d'être has undoubtedly been weakened.

ARSA's attack on a Myanmar military convoy in northern Rakhine State on 5 January 2018 demonstrated its determination to remain relevant as a fighting force. ${ }^{27}$ Its immediate statement claiming responsibility, and its subsequent statement the same month rejecting repatriation proposals, also made an apparent attempt to position the group as the political voice of the Rohingya. ${ }^{28}$

There is evidence, albeit thus far limited, that ARSA is organising in the Bangladesh camps. First, some acts of violence in the camps can be plausibly linked to ARSA. There have been a small number of killings of majhis and other leaders attributed in the media to criminals or to the fact that the victims were working with the Bangladeshi authorities on potential returns. It seems, however, that in at least a few of these cases, the person killed may have been on an ARSA hit list since before the exodus. ${ }^{29}$

Second, ARSA members themselves claim to have influence over the majhis. Indeed, it would be surprising if some of the majhis were not linked even more directly to the group given the extent of ARSA's previous mobilisation and support in Rakhine State - and its success in imposing its will through violence. This combination of persuasion and targeted violence is precisely analogous to ARSA's earlier tactics in

\footnotetext{
${ }^{25}$ Crisis Group interviews, refugees, ARSA members and representatives of humanitarian agencies, Bangladesh, November 2017-March 2018. Refugees are able to move freely within and between camps, but they are restricted from travelling to Cox's Bazar or Chittagong, except with medical referral. It has up to now been easy for them to travel to the town of Teknaf, but since early March soldiers at checkpoints have started asking about reasons for travel.

${ }^{26}$ See Crisis Group Report, A New Muslim Insurgency in Rakhine State, op. cit.

27 "Five security personnel injured in ambush attack in Northern Rakhine", GNLM, 6 January 2018. ${ }^{28}$ ARSA press statements, "Turaing ambush against the Burmese terrorist army”, 7 January 2018; and "Burmese terrorist government's unreasonable repatriation plan for Rohingya refugees from Bangladesh”, 20 January 2018. Available on the group's Twitter account, @ARSA_Official.

${ }^{29}$ Crisis Group interviews, refugees, ARSA members and others with knowledge of the situation, Bangladesh, November 2017-March 2018. See also "Rohingya leader shot dead in Cox's Bazar", Dhaka Tribune, 20 January 2018; "Second camp 'leader' killed in Bangladesh refugee camp”, AFP, 23 January 2018; "Bangladesh tightens security in Rohingya camps", The Irrawaddy, 2 February 2018.
} 
Myanmar. Another opportunity for ARSA to exert its influence is through its members or supporters volunteering as night watchmen. Finally, religious leaders - some of whom were key ARSA community mobilisers and leaders in Rakhine State - continue to be important in the camps. ${ }^{30}$

ARSA's presence in the camps does not, however, imply that it can sustain an insurgency in Rakhine State, even if that were to remain its main focus, which itself is not certain. The strong presence of Bangladeshi army and intelligence personnel in and around the camps, plus the geography of the area and its high population density, means that ARSA will find it difficult to reorganise in Bangladesh without the authorities knowing. Now that the majority of the Rohingya population is in Bangladesh with little prospect of return, other objectives, notably organising to lobby for improved living conditions and opportunities in Bangladesh, are likely to assume greater importance for refugees - and hence for any group that draws its constituency from them - than mobilising for an insurgency across the border. Much, therefore, depends on how the political situation in Bangladesh evolves.

\section{B. Refugee Views on ARSA and the Use of Violence}

Detailed Crisis Group discussions with refugees indicate that the tragedy that has befallen the Rohingya, sparked by the ARSA attacks, has influenced perceptions of ARSA in different ways. Some refugees adopt the view that, whether or not those attacks had taken place, the Myanmar authorities would have found a way to drive them from their land. Others believe that the Rohingya lost everything as a result of the attacks, while gaining nothing. Many expressed the hope that something positive might come from their plight, as the Rohingya have never before received so much global attention. "Finally, the world has learned how much we have been suffering" was a commonly aired sentiment. ${ }^{31}$

Many of those who had supported or engaged in ARSA's resistance saw violence as a last resort. They believed that ARSA's rationale was bolstered by fatwas (religious judicial opinions or binding religious edicts) from Rohingya clerics in Rakhine State and in the diaspora declaring armed struggle to be legitimate or even obligatory. On the other hand, other voices among the Rohingya, including leading clerics, had long counselled against violence and continue to do so..$^{32}$

This question was the subject of a detailed media report in Bangladesh in March $2018 .{ }^{33}$ The article cited the issuance of a fatwa by 47 Rohingya muftis (Islamic scholars who interpret religious law) condemning any act of jihad, even for self-defence, against Myanmar. ${ }^{34}$ It stated that Deobandi madrassas in Bangladesh, India and Pa-

\footnotetext{
${ }^{30}$ Crisis Group interviews, refugees, ARSA members and others with knowledge of the situation, October 2017-March 2018.

${ }^{31}$ Crisis Group interviews, refugees, October 2017-March 2018.

${ }^{32}$ See Crisis Group Reports, The Politics of Rakhine State and A New Muslim Insurgency in Rakhine State, op. cit.

33 "Rohingya muftis prohibit jihad and self-defense", Dhaka Tribune, March 2018.

${ }^{34}$ The Arabic root of "jihad" refers to striving in God's service. Many Muslims find its use in the political violence context imprecise and offensive, reducing a complex religious concept to warmaking. In reference to violence, it can encompass insurgency and guerrilla war as well as terrorism. For the vast majority of Muslims, today's “jihadists” pervert Islam's tenets. But it is hard to escape
} 
kistan backed the fatwa (Deobandi Islam is a Sunni revivalist movement to which the most influential Rohingya clerics adhere).

There has always been, and continues to be, a strong current of thought among Rohingya that opposes any form of violent resistance. Yet two considerations are relevant to assessing whether the fatwa represents a significant shift in sentiment away from ARSA and militancy among the Rohingya. First, it is not new; it was issued in October 2017, at the height of the exodus, a time when Rohingya leaders felt it was vital to reassure Bangladesh that the refugees did not represent a security threat. Second, the fatwa did not categorically reject the idea of violent resistance; it did, however, caution against it at the time of issuance. That is, it was not a rejection of ARSA as such, but rather of particular tactics the signatories viewed as premature or misguided. ${ }^{35}$

Many observers have expressed concern about the risk of transnational jihadist groups - that is, groups such as al-Qaeda in the Indian Subcontinent, the Islamic State or their Bangladeshi affiliates - exploiting the Rohingya crisis to mobilise or recruit in the camps. While this concern is legitimate, given the security landscape in Bangladesh, there is no evidence that such exploitation is happening, nor that a counterterrorism lens is useful for understanding the evolving situation in the camps. ARSA has always distanced itself from transnational jihadism, and the group, its members and refugees interviewed continue to do so.$^{36}$ The Bangladeshi authorities share this assessment. ${ }^{37}$

the term. Groups such as al-Qaeda and ISIS self-identify as "jihadist", and while jihad has long been an element of virtually all schools of Islam, a nascent "jihadist" ideology has emerged that is more than a reflection of this history; ideologues borrow from other traditions and at times show frustration with Salafi doctrinal rigidity that might constrain combat tactics. Though big differences exist, "jihadist" groups share some tenets: that fighting to return society to a purer Islam is proper; that violence against rulers whose policies they deem in conflict with Islamic imperatives as they understand them is justified; and that, in fact, there is a duty to use violence if Muslim rulers abandon those imperatives. This report's use of "jihadist" is not meant to add legitimacy to this interpretation or to detract from efforts to promote alternative interpretations. For more about Crisis Group's use of this term, see Crisis Group Special Report $\mathrm{N}^{\circ} 1$, Exploiting Disorder: Al-Qaeda and the Islamic State, 14 March 2016, p. 2.

${ }^{35}$ Crisis Group interviews, muftis who signed the fatwa, Bangladesh, March 2018.

${ }^{36}$ Ibid.

${ }^{37}$ Crisis Group interviews, Bangladesh intelligence official, Dhaka, April 2018; Bangladesh security officials, Cox's Bazar, January 2018. This assessment will be examined in greater detail in a forthcoming Crisis Group report on the challenges the Rohingya crisis poses for Bangladesh. 


\section{What Next for the Crisis?}

\section{A. In Bangladesh}

There is little prospect that the situation in Rakhine State will improve sufficiently in the near future for voluntary repatriation to be conceivable. The future of the refugees is thus very much dependent on developments in Bangladesh.

Little suggests Bangladeshi authorities are inclined to force refugees back to $\mathrm{My}$ anmar. Sympathy for the Rohingya among the Bangladeshi populace remains widespread, and the government calculates that pressure on the refugees to return would be ill advised in an election year. ${ }^{38}$ It would also damage relations with donor countries that are funding the $\$ 1.2$ billion per year humanitarian operation. Public opinion and government calculations could easily shift, however. Two factors will be especially important.

First is the sentiment of the host community in Cox's Bazar. Currently, relations between refugees and locals are relatively good - better, in fact, than during the 1990 s crisis, even though the numbers of refugees now are far higher. But continued positive relations cannot be taken for granted. In the two sub-districts where the refugee camps are located (Ukhia and Teknaf), refugees outnumber the local population two to one. The rapid influx has placed a huge burden on the host community prices have risen, day labour rates gone down, farmlands been lost, transport times lengthened, and deforestation and environmental degradation worsened. Locals worry about the health and security implications of the camps. Their sympathy could easily dry up as the crisis becomes protracted. ${ }^{39}$

Second is whether sentiment in Bangladesh as a whole and the government's stance in particular shifts after the elections. This could happen even if the current Awami League government holds onto power, which seems likely. Bangladesh has always insisted that the refugees must return to Myanmar, and it has rejected the idea of local integration. Pressure on refugees to return to Myanmar remains a future possibility, even if the Bangladeshi population and government for now largely welcome them.

At the same time, Bangladesh has made clear that it is making contingency arrangements. It has moved forward with a $\$ 280$ million plan to resettle 100,000 Rohingya refugees on an isolated and flood-prone island, Bhasan Char, in the Bay of Bengal. The Bangladeshi navy issued a tender on 24 November 2017 for development of the island camp and necessary flood defences; the government says it has no timeline for the development - indeed, no allocation from the budget has reportedly yet been secured ${ }^{40}$ - and that no Rohingya will be moved against their will. The plan has alarmed aid agencies, however, who have concerns about the site's suitability and

\footnotetext{
${ }^{38}$ Crisis Group interview, opinion polling professional, Dhaka, April 2018. This assessment will be examined in a forthcoming Crisis Group report on the challenges the Rohingya crisis poses for Bangladesh.

${ }^{39}$ Crisis Group interviews, members of local community and refugees, Cox's Bazar, Bangladesh, November 2017-March 2018. See also "Rohingya refugees test Bangladeshi welcome as prices rise and repatriation stalls", Reuters, 28 February 2018.

${ }^{40}$ Crisis Group interview, member of Bangladeshi civil society who has closely followed the matter, May 2018.
} 
the difficulty of access to it. Refugees strongly oppose moving to the island, but they seem to think that the scheme will never get off the ground. If their relocation were to appear imminent, serious resistance could be anticipated..$^{41}$ Demonstrations already took place in January, when refugees believed they might be pressured to repatriate..$^{2}$

In general, refugees have strong communications networks and, despite being mostly illiterate (the Rohingya language has no written form in general usage), have access to considerable information about their predicament and the attendant international debate. Almost all refugee families also have access to a smartphone - like Myanmar as a whole, which has one of the world's highest smartphone penetration rates. ${ }^{43}$ These devices are now connected to Bangladeshi networks through SIM cards purchased on the black market (refugees are officially prohibited from purchasing a Bangladeshi SIM card). WhatsApp serves as essentially the sole means of communication for Rohingya, mostly via sharing of audio files and video clips. Most refugees are members of multiple WhatsApp groups, giving them access to news and religious teachings, as well as a connection to their families, including those still in Myanmar or in other countries. ${ }^{44}$ Some of these WhatsApp groups also could serve as a means of coordination and mobilisation, particularly should the refugees face major challenges, such as forced repatriation or resettlement to the island.

To the extent that refugees have had time to think about their future in any detail, most say they want to return to Rakhine State but are resigned to the fact that they may have to wait for an extended period in Bangladesh before that is possible. Very few express an intention to go to third countries. In any case, possibilities for doing so are limited: the smuggling route by boat across the Bay of Bengal to Malaysia remains extremely difficult, the land route via India across Myanmar to Thailand is expensive and fraught with peril, and only a handful of refugees have the resources and connections to leave by air. Informal integration in Bangladesh is also more difficult than in the past. Authorities now restrict marriages between refugees and locals, and because Bangladesh IDs are now biometric, they are more difficult and expensive to obtain on the black market than they were previously. Some refugees have avoided entering the camps and being registered, to make it easier to move around and to leave - but their number appears to be very small (it includes some senior ARSA members, as mentioned above). ${ }^{45}$

\footnotetext{
${ }^{41}$ Crisis Group interviews, refugees and aid agency representatives, Cox’s Bazar, Bangladesh, November 2017-March 2018. See also "Floating island: New home for Rohingya refugees emerges in Bay of Bengal”, Reuters, 22 February 2018; "Dhaka bemoans lack of funding for Rohingya refugee island", Reuters, 27 March 2018.

42 "Rohingya refugees in Bangladesh protest repatriation move", AFP, 20 January 2018.

${ }^{43}$ Smartphone penetration in Myanmar is 80 per cent, significantly higher than in its neighbours (Singapore is 78 per cent and Thailand 59 per cent). Realizing Digital Myanmar, Telenor, February 2018.

${ }^{44}$ Of the many WhatsApp groups, some connect people from a particular village in Rakhine (eg, the Taung Bazar group and the Badanar group); others are content-based, such as the Rohingya Ettafaq (Unity) group, the Rohingya social media group, the Arakan Azad (Freedom) group and the Rohingya National news group.

${ }^{45}$ Crisis Group interviews, refugees and analysts, Bangladesh, November 2017-March 2018.
} 


\section{B. In Northern Rakhine State}

Beyond building the physical infrastructure to support limited returns, Myanmar has made no real progress in creating conditions on the ground that would give refugees the confidence to return. In the meantime, among the 100,000-150,000 Rohingya remaining in northern Rakhine, a few thousand per month continue to leave for Bangladesh.

Rohingya in northern Rakhine report that they have no wish to leave unless circumstances compel them to do so. Those that are leaving cite reasons including their inability to obtain food or medical treatment for serious illness or injury; the confiscation of their land; and accusations by the authorities that a family member is an ARSA member. ${ }^{46}$ Recent arrivals from north Rathedaung and south Buthidaung reported fleeing due to food shortages and land confiscation (such as for a new border guard police base in Ah Lel Chaung village-tract). They also relate that while there are no direct threats from police or security forces, continued discrimination and restrictions make it impossible to continue trade and rural livelihoods. The rural economy has virtually collapsed, and poor people say they have to survive on the few day labour opportunities remaining or rely on remittances from family or friends in Yangon or overseas. ${ }^{47}$

Much of Maungdaw township's rural areas and other parts of northern Rakhine are now virtually depopulated. These areas will not remain as they are, frozen in time pending eventual repatriation in the months or years to come. Many villages were burned to the ground, and those - as well as some that were not burned - are now being bulldozed and trees and vegetation uprooted. Non-Muslim villages are expanding and new migrants arriving, with some new villages being constructed on what were Rohingya villages and lands. The government, or private companies under their direction, are constructing new roads and extending the electrical grid. The military and Border Guard Police are rolling out additional security infrastructure. The government is pushing for development projects and Myanmar conglomerates have been encouraged to look at business opportunities in the area. Whether these activities reflect a government strategy to remake northern Rakhine as a Buddhistmajority area - as some rights groups and other observers have claimed and as Rakhine nationalists have advocated - is unclear. ${ }^{48}$ But whatever the motives, the consequence will be that with boundaries and landmarks erased, refugees' return to their original homes and lands will be near impossible, and the possibility of any return at all greatly reduced.

\footnotetext{
${ }^{46}$ Crisis Group interviews, Rohingya villagers in northern Rakhine State and recently arrived refugees in Bangladesh, January-March 2018. See also "Confidential briefing note on the Maung Nu massacre and its aftermath”, Arakan Project, 22 February 2018 (non-public); and "Remaking Rakhine state," Amnesty International, March 2018.

47 Ibid.

${ }^{48}$ For details of the changes that are taking place, see "Remaking Rakhine state", Amnesty International, March 2018. See also "Burma is pumping millions into rebuilding Rakhine, but is it for the Rohingya?”, Washington Post, 14 March 2018; "With Rohingya gone, Myanmar's ethnic Rakhine seek Muslim-free 'buffer zone”, AFP, 16 March 2018; “We have no intention of hiding anything': Myanmar rebuilding in Maungdaw, Rakhine state”, Channel News Asia, 20 March 2018.
} 
In the meantime, relations between the (Buddhist) ethnic Rakhine population and the government have deteriorated sharply in 2018. The Rakhine State crisis thus has become three-sided, pitting not only the Rakhine against the Rohingya but Myanmar authorities against both, which further undermines prospects of stability and of addressing the Rohingya's plight. Two incidents in particular have ignited ethnic Rakhine anger. First was a police crackdown in January on an anti-government demonstration in the ancient Rakhine capital of Mrauk-U that left seven Rakhine participants dead and at least a dozen hospitalised; they had been protesting a government decision to ban events commemorating the 223rd anniversary of the fall of the Arakan Kingdom. The shootings were followed two days later by the arrest of the most prominent Rakhine politician, the lower house MP Dr Aye Maung, for comments at a literature festival that the authorities said were seditious and supportive of the Arakan Army. He and a second person were subsequently charged with high treason, which carries a mandatory sentence of death or life imprisonment. ${ }^{49}$

The perceived lack of a credible government response or accountability for the police shooting, and Dr Aye Maung's ongoing prosecution in Sittwe court, both continue to inflame local sentiment. On 30 January, the Mrauk-U administrator was stabbed to death, likely because of his perceived role in the crackdown. In the early hours of 24 February, three bombs exploded in Sittwe, at locations that appeared to target the government - near a senior official's home, a court and a government office, respectively. A policeman was injured. Three other devices were found and deactivated. No group claimed responsibility but there has been widespread speculation that it may have been the Arakan Army, the only group seen as having the motive and capacity. If it is responsible, the murder and bombings would mark a significant escalation for a group that normally only attacks military targets in rural areas. On 17 January, it had issued a statement threatening "serious retaliatory measures" against those responsible for the Mrauk-U shootings..$^{50}$

At a time when it must grapple with unprecedented challenges in Rakhine State, the government now faces the additional problem of deepening Rakhine nationalist disaffection, which could tip into instability or violence. The government would be well advised to ease tensions with the Rakhine community. Of course, this should not include acquiescing to Rakhine demands that are contrary to human rights norms or Myanmar's international legal obligations; nor should it detract from the obligation to hold Rakhine politicians or anyone else accountable for hate speech or inciting violence. But the government should review its high treason prosecutions against Aye Maung and his co-accused, which may not serve the public interest at this time, and ensure there is accountability for the police shootings in Mrauk-U.

\footnotetext{
${ }^{49}$ Burma Penal Code section 122, as amended by Burma Act XX, 1950. Death sentences are still handed down, but judicial executions are no longer carried out in Myanmar. For details on the incidents, see "7 people reported dead after police crackdown on protest in Mrauk-U”, The Irrawaddy, 17 January 2018; “MP, author charged with high treason”, The Irrawaddy, 9 February 2018.

${ }^{50}$ United League of Arakan/Arakan Army statement, 17 January 2018. See also "Three bombs rock Myanmar's northwestern city Sittwe, policeman injured”, Reuters, 24 February 2018.
} 


\section{Role of the International Community}

The Rohingya crisis presents a significant dilemma for the international community. On one hand, it is vital to insist on the right of the Rohingya to return home and Myanmar's obligation to create conditions conducive to that, as well as to pursue accountability. On the other, no voluntary repatriation is feasible for the foreseeable future, which means concerted efforts are required to ease the burden on Bangladesh and provide alternative options for the refugees.

Until now, many countries have been concerned that explicitly acknowledging that the refugees are unlikely to go home would relieve pressure on Myanmar to accept them back and could be seen as rewarding the architects of ethnic cleansing. But the harsh reality is that concerted international pressure thus far has not altered Myanmar's political stance on this issue and even such increased efforts as could be plausibly achieved - given that China and Russia remain opposed to any punitive action from the Security Council - are highly unlikely to do so. The risk of failing to develop long-term strategies for the refugees now is not just that hundreds of thousands of people will continue to live in limbo. It is also that the status quo could morph in dangerous ways. ${ }^{51}$ If host communities or national political sentiment in Bangladesh turns against the refugees, the government may pressure them to return against their will or force them into more isolated camps in Bangladesh, such as those being constructed on Bhasan island. Such developments could prompt instability or violence on either side of the border - in Bangladesh, because the refugees would resist, perhaps even violently, and in Myanmar, because a forced return could lead to communal clashes with hostile non-Muslim communities and could prompt ARSA to mobilise in support of returnees.

In Bangladesh, it is vital that international donors not only support the humanitarian operation by funding the Joint Response Plan,${ }^{52}$ but also that they invest heavily in development support for the affected part of Bangladesh, to reduce the burden on local communities and the government and to create an environment more conducive to any future local integration.

In Myanmar's Rakhine State, the situation needs to be stabilised so that the lives and livelihoods of the Rohingya and other Muslim communities who remain - in all parts of the state - are more secure and the exodus to Bangladesh from the north of the state ends. This challenge is not primarily one of development, but one of policy. As an immediate step in northern Rakhine, the government needs to ease the draconian restrictions on freedom of movement - curfews, checkpoints and other impediments - so that agriculture, fishing and trading can resume in rural areas and there is better access to services. It should follow through on promises of closer cooperation by providing unfettered access to the UN and its international NGO partners including by quickly reaching agreement on the memorandum of understanding it is discussing with UNHCR and the UN Development Program. In the longer term, the

\footnotetext{
${ }^{51}$ See Crisis Group Report, Myanmar's Rohingya Crisis Enters a Dangerous New Phase, op. cit.

${ }^{2}$ The Joint Response Plan for the Rohingya Humanitarian Crisis, launched by UNHCR and IOM in March 2018, is an appeal for \$951 million to support the humanitarian operation for Rohingya refugees in Bangladesh for the period March-December 2018 (http://reporting.unhcr.org/node/ 20415).
} 
only credible solution is progress on desegregation, citizenship and equality in all parts of Rakhine State, as outlined in the report of the Rakhine Advisory Commission chaired by Kofi Annan.

The UN Security Council visit to Bangladesh and Myanmar from 29 April to 1 May demonstrates the deep concern of Council members and will likely strengthen their commitment to ongoing scrutiny of the situation. ${ }^{53}$ The UN secretary-general's appointment in advance of the visit of a special envoy for Myanmar, Swiss diplomat Christine Schraner Burgener, gives the UN an important new avenue for political engagement with the government. ${ }^{54}$ These developments - in particular, a strategic combination of continued Council scrutiny with sustained diplomatic engagement by the special envoy - could create new opportunities to make at least some progress on the immediate steps outlined above. Indeed, at the end of the Security Council visit to Myanmar, State Counsellor Aung San Suu Kyi issued a press release stating that "this is the appropriate time" for strengthened cooperation with the UN on Rakhine State and expressing confidence that the Council's visit would be "an important turning point in this regard". ${ }^{55}$ This signal, along with the appointment of President Win Myint at the end of March 2018, which could lead to redistribution of political authority in the government, may open space for changes in the government's approach. Progress on longer-term solutions through implementation of the Annan Commission recommendations will remain extremely difficult.

\footnotetext{
${ }^{53}$ For a summary of the visit, see the series of "dispatches from the field" by Security Council Report, available at www.securitycouncilreport.org/myanmar.

54 "Secretary-General Appoints Christine Schraner Burgener of Switzerland as Special Envoy on Myanmar”, UN Press Release, 26 April 2018.

55 Press Release, Ministry of the Office of the State Counsellor, Naypyitaw, 1 May 2018.
} 


\section{Conclusion}

The massive exodus of Rohingya refugees to Bangladesh has slowed to a few hundred per week. But no repatriation has taken place or appears likely. The large majority of Rohingya are now in Bangladesh, living as refugees in squalid mega-camps. The threat of landslides and floods looms large as the monsoon and cyclone season approaches, with a concomitant risk of waterborne disease. Those who remain in northern Rakhine State are in a precarious position, unable to move freely or sustain livelihoods; many may be forced to flee to Bangladesh in the coming weeks and months.

Efforts to pursue accountability - whether through the International Criminal Court or other mechanisms - remain vital, as does pressing Myanmar to improve the situation in northern Rakhine and create conditions conducive to voluntary return. At the same time, large-scale voluntary returns for now are highly unlikely. The imperative must be to find sustainable solutions for the refugees in Bangladesh. In addition to supporting the humanitarian operation, donors should invest in developing the affected area of Bangladesh to help host communities and to create conditions amenable to local integration. The reluctance of the international actors to openly acknowledge that the hundreds of thousands of Rohingya forced out by Myanmar's military operations are unlikely to return any time soon is understandable. But the lack of sustained political discussions and concrete planning for the refugees' extended stay in Bangladesh risks worsening their plight and could propel the crisis in a dangerous new direction.

Brussels, 16 May 2018 


\section{Appendix A: Map of Myanmar}

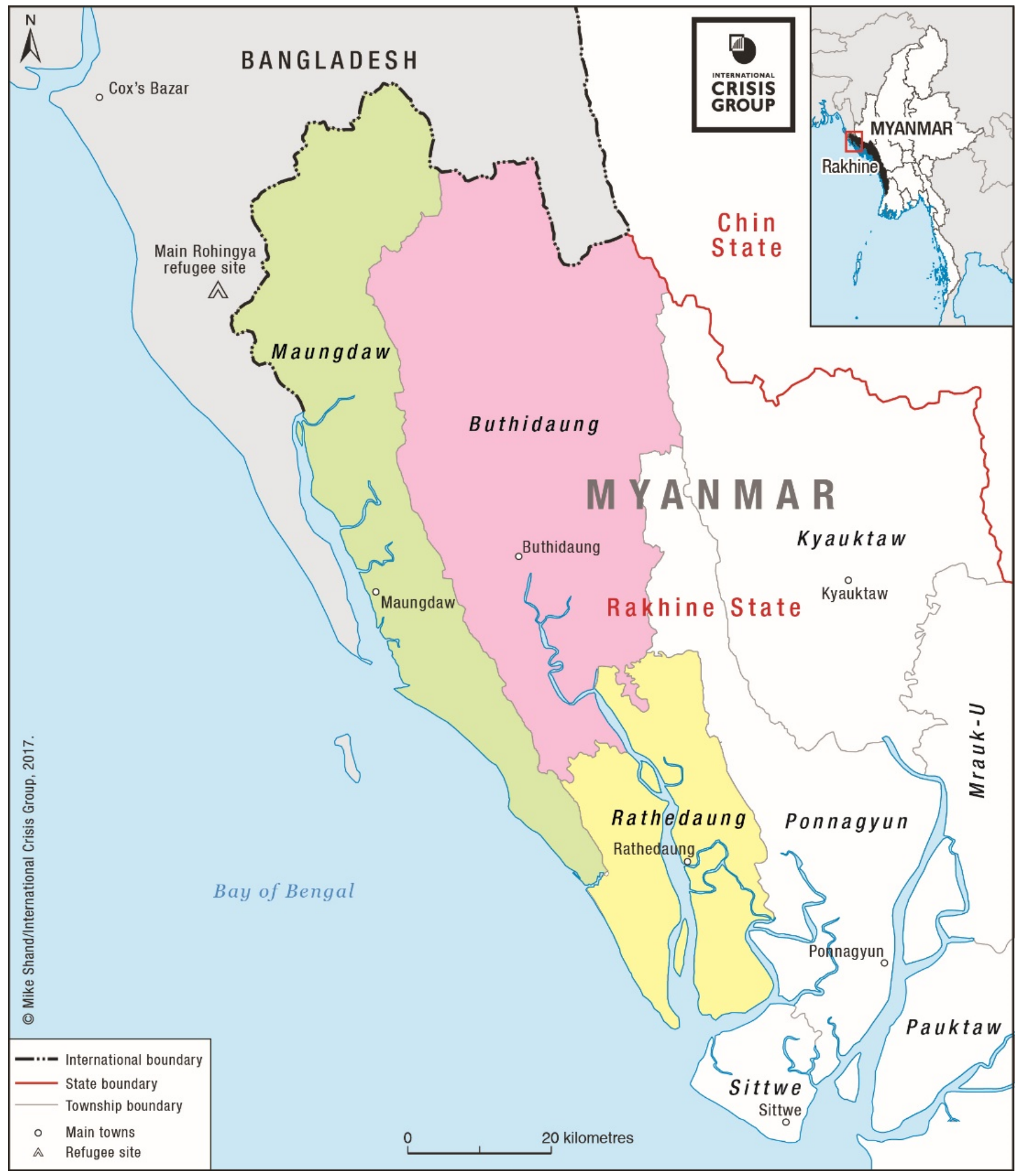




\section{Appendix B: About the International Crisis Group}

The International Crisis Group (Crisis Group) is an independent, non-profit, non-governmental organisation, with some 120 staff members on five continents, working through field-based analysis and high-level advocacy to prevent and resolve deadly conflict.

Crisis Group's approach is grounded in field research. Teams of political analysts are located within or close by countries or regions at risk of outbreak, escalation or recurrence of violent conflict. Based on information and assessments from the field, it produces analytical reports containing practical recommendations targeted at key international, regional and national decision-takers. Crisis Group also publishes CrisisWatch, a monthly early warning bulletin, providing a succinct regular update on the state of play in up to 70 situations of conflict or potential conflict around the world.

Crisis Group's reports are distributed widely by email and made available simultaneously on its website, www.crisisgroup.org. Crisis Group works closely with governments and those who influence them, including the media, to highlight its crisis analyses and to generate support for its policy prescriptions.

The Crisis Group Board of Trustees - which includes prominent figures from the fields of politics, diplomacy, business and the media - is directly involved in helping to bring the reports and recommendations to the attention of senior policymakers around the world. Crisis Group is chaired by former UN Deputy Secretary-General and Administrator of the United Nations Development Programme (UNDP), Lord Mark Malloch-Brown. Its Vice Chair is Ayo Obe, a Legal Practitioner, Columnist and TV Presenter in Nigeria.

Crisis Group's President \& CEO, Robert Malley, took up the post on 1 January 2018. Malley was formerly Crisis Group's Middle East and North Africa Program Director and most recently was a Special Assistant to former U.S. President Barack Obama as well as Senior Adviser to the President for the Counter-ISIL Campaign, and White House Coordinator for the Middle East, North Africa and the Gulf region. Previously, he served as President Bill Clinton's Special Assistant for Israeli-Palestinian Affairs.

Crisis Group's international headquarters is in Brussels, and the organisation has offices in ten other locations: Bishkek, Bogota, Dakar, Kabul, Islamabad, Istanbul, Nairobi, London, New York, and Washington, DC. It has presences in the following locations: Abuja, Algiers, Bangkok, Beirut, Caracas, Gaza City, Guatemala City, Hong Kong, Jerusalem, Johannesburg, Juba, Mexico City, New Delhi, Rabat, Sanaa, Tblisi, Toronto, Tripoli, Tunis, and Yangon.

Crisis Group receives financial support from a wide range of governments, foundations, and private sources. Currently Crisis Group holds relationships with the following governmental departments and agencies: Australian Department of Foreign Affairs and Trade, Austrian Development Agency, Danish Ministry of Foreign Affairs, Dutch Ministry of Foreign Affairs, European Union Instrument contributing to Stability and Peace, European Commission, Directorate General for Neighbourhood Enlargement Negotiations, Finnish Ministry for Foreign Affairs, French Development Agency, French Ministry of Europe and Foreign Affairs, Irish Aid, Japan International Cooperation Agency, Principality of Liechtenstein, Luxembourg Ministry of Foreign Affairs, New Zealand Ministry of Foreign Affairs and Trade, Norwegian Ministry of Foreign Affairs, Swedish Ministry of Foreign Affairs, and the Swiss Federal Department of Foreign Affairs.

Crisis Group also holds relationships with the following foundations: Carnegie Corporation of New York, Heinrich Böll Stiftung, Henry Luce Foundation, John D. and Catherine T. MacArthur Foundation, Konrad Adenauer Stiftung, Korea Foundation, Oak Foundation, Omidyar Network Fund, Open Society Foundations, Ploughshares Fund, Robert Bosch Stiftung, Rockefeller Brothers Fund, and Wellspring Philanthropic Fund.

May 2018 


\section{Appendix C: Reports and Briefings on Asia since 2015}

\section{Special Reports}

Exploiting Disorder: al-Qaeda and the Islamic State, Special Report N¹, 14 March 2016 (also available in Arabic and French).

Seizing the Moment: From Early Warning to EarIy Action, Special Report N², 22 June 2016.

Counter-terrorism Pitfalls: What the U.S. Fight against ISIS and al-Qaeda Should Avoid, Special Report N³, 22 March 2017.

\section{North East Asia}

Stirring up the South China Sea (III): A Fleeting Opportunity for Calm, Asia Report N²67, 7 May 2015 (also available in Chinese).

North Korea: Beyond the Six-Party Talks, Asia Report N²69, 16 June 2015.

Stirring up the South China Sea (IV): Oil in Troubled Waters, Asia Report N²75, 26 January 2016 (also available in Chinese).

East China Sea: Preventing Clashes from Becoming Crises, Asia Report $N^{\circ} 280,30$ June 2016.

China's Foreign Policy Experiment in South Sudan, Asia Report N²88, 10 July 2017 (also available in Chinese).

The Korean Peninsula Crisis (I): In the Line of Fire and Fury, Asia Report $\mathrm{N}^{\circ} 293,23$ January 2018 (also available in Chinese).

The Korean Peninsula Crisis (II): From Fire and Fury to Freeze-for-Freeze, Asia Report N²94, 23 January 2018 (also available in Chinese).

\section{South Asia}

Mapping Bangladesh's Political Crisis, Asia Report N²64, 9 February 2015.

Women, Violence and Conflict in Pakistan, Asia Report N²65, 8 April 2015.

The Future of the Afghan Local Police, Asia Report N²68, 4 June 2015.

Revisiting Counter-terrorism Strategies in Pakistan: Opportunities and Pitfalls, Asia Report N²71, 22 July 2015.

Sri Lanka Between Elections, Asia Report N²72, 12 August 2015.

Winning the War on Polio in Pakistan, Asia Report N²73, 23 October 2015.

Nepal's Divisive New Constitution: An Existential Crisis, Asia Report N²76, 4 April 2016.

Political Conflict, Extremism and Criminal Justice in Bangladesh, Asia Report N²77, 11 April 2016.

Sri Lanka: Jumpstarting the Reform Process, Asia Report N²78, 18 May 2016.

Pakistan's Jihadist Heartland: Southern Punjab, Asia Report №279, 30 May 2016.

Pakistan: Stoking the Fire in Karachi, Asia Report N²84, 15 February 2017.
Afghanistan: The Future of the National Unity Government, Asia Report N285, 10 April 2017.

Sri Lanka's Transition to Nowhere, Asia Report N²86, 16 May 2017.

Sri Lanka's Conflict-Affected Women: Dealing with the Legacy of War, Asia Report N²89, 28 July 2017.

Countering Jihadist Militancy in Bangladesh, Asia Report N²95, 28 February 2018.

\section{South East Asia}

Myanmar's Electoral Landscape, Asia Report N²66, 28 April 2015 (also available in Burmese).

Southern Thailand: Dialogue in Doubt, Asia Report N²70, 8 July 2015.

Myanmar's Peace Process: A Nationwide Ceasefire Remains Elusive, Asia Briefing $N^{\circ} 146,16$ September 2015 (also available in Burmese).

The Myanmar Elections: Results and Implications, Asia Briefing N¹47, 9 December 2015 (also available in Burmese).

Thailand's Lengthening Roadmap to Elections, Asia Report N²74, 10 December 2015.

The Philippines: Renewing Prospects for Peace in Mindanao, Asia Report N²81, 6 July 2016.

Myanmar's New Government: Finding Its Feet?, Asia Report N²82, 29 July 2016 (also available in Burmese).

Southern Thailand's Peace Dialogue: No Traction, Asia Briefing N¹48, 21 September 2016.

Myanmar's Peace Process: Getting to a Political Dialogue, Asia Briefing N`149, 19 October 2016 (also available in Burmese).

Myanmar: A New Muslim Insurgency in Rakhine State, Asia Report N²83, 15 December 2016 (also available in Burmese).

Building Critical Mass for Peace in Myanmar, Asia Report N²87, 29 June 2017 (also available in Burmese).

Buddhism and State Power in Myanmar, Asia Report N²90, 5 September 2017 (also available in Burmese).

Jihadism in Southern Thailand: A Phantom Menace, Asia Report N²91, 8 November 2017 (also available in Thai and Malay).

Myanmar's Rohingya Crisis Enters a Dangerous New Phase, Asia Report N²92, 7 December 2017 (also available in Burmese). 
Appendix D: International Crisis Group Board of Trustees

\section{CO-CHAIR \\ Lord (Mark) Malloch-Brown Former UN Deputy Secretary-General and Administrator of the United Nations Development Programme (UNDP)}

\section{PRESIDENT \& CEO \\ Robert Malley}

Former White House Coordinator for the Middle East, North Africa and the Gulf region

\section{VICE-CHAIR}

\section{Ayo Obe}

Chair of the Board of the Gorée Institute (Senegal); Legal Practitioner (Nigeria)

\section{OTHER TRUSTEES}

\section{Fola Adeola}

Founder and Chairman, FATE Foundation

\section{Celso Amorim}

Former Minister of External Relations of Brazil; Former Defence Minister

\section{Hushang Ansary}

Chairman, Parman Capital Group LLC:

Former Iranian Ambassador to the

U.S. and Minister of Finance and

Economic Affairs

\section{Nahum Barnea}

Political Columnist, Israe

\section{Kim Beazley}

Former Deputy Prime Minister of Australia and Ambassador to the U.S.; Former Defence Minister

\section{Carl Bildt}

Former Prime Minister and Foreign Minister of Sweden

\section{Emma Bonino}

Former Foreign Minister of Italy and European Commissioner for Humanitarian Aid

\section{Cheryl Carolus}

Former South African High

Commissioner to the UK and Secretary General of the African National Congress (ANC)

Maria Livanos Cattaui Former Secretary General of the International Chamber of Commerce

\section{Wesley Clark}

Former NATO Supreme Allied Commander

\section{Sheila Coronel}

Toni Stabile Professor of Practice in Investigative Journalism; Director,

Toni Stabile Center for Investigative Journalism, Columbia University

\section{Frank Giustra}

President \& CEO, Fiore Group

\section{Mo Ibrahim}

Founder and Chair, Mo Ibrahim

Foundation; Founder, Celte

International

\section{Wolfgang Ischinge}

Chairman, Munich Security

Conference; Former German Deputy

Foreign Minister and Ambassador to the UK and U.S.

\section{Yoriko Kawaguchi}

Former Foreign Minister of Japan;

former Environment Minister

Wadah Khanfar

Co-Founder, Al Sharq Forum; forme Director General, Al Jazeera Network

\section{Wim Kok}

Former Prime Minister of the Netherlands

\section{Andrey Kortunov}

Director General of the Russian International Affairs Council

\section{Ivan Krastev}

Chairman of the Centre for Liberal Strategies (Sofia); Founding Board Member of European Council on

Foreign Relations

\section{Ricardo Lagos}

Former President of Chile

Joanne Leedom-Ackerman

Former International Secretary of PEN International; Novelist and journalist, U.S.

\section{Helge Lund}

Former Chief Executive BG Group (UK) and Statoil (Norway)

\section{Shivshankar Menon}

Former Foreign Secretary of India; former National Security Advisor

\section{Naz Modirzadeh}

Director of the Harvard Law Schoo Program on International Law and Armed Conflict

\section{Saad Mohseni}

Chairman and Chief Executive Officer of MOBY Group

\section{Marty Natalegawa}

Former Minister of Foreign Affairs of Indonesia, Permanent Representative to the UN, and Ambassador to the UK

\section{Roza Otunbayeva}

Former President of the Kyrgyz Republic; Founder of the International Public Foundation "Roza Otunbayeva Initiative"

\section{Thomas R. Pickering}

Former U.S. Under Secretary of State and Ambassador to the UN, Russia, India, Israel, Jordan, El Salvador and Nigeria

\section{Olympia Snowe}

Former U.S. Senator and Member of the House of Representatives

\section{Javier Solana}

President, ESADE Center for Global Economy and Geopolitics; Distinguished Fellow, The Brookings Institution

\section{Alexander Soros}

Deputy Chair of the Global Board, Open Society Foundations

\section{George Soros}

Founder, Open Society Foundations and Chair, Soros Fund Management

\section{Pär Stenbäck}

Former Minister of Foreign Affairs and of Education, Finland; Chairman of the European Cultural Parliament

\section{Jonas Gahr Støre}

Leader of the Labour Party and Labour Party Parliamentary Group; former Foreign Minister of Norway

\section{Lawrence H. Summers}

Former Director of the U.S. National Economic Council and Secretary of the U.S. Treasury; President Emeritus of Harvard University

Helle Thorning-Schmidt CEO of Save the Children International; former Prime Minister of Denmark

\section{Wang Jisi}

Member, Foreign Policy Advisory Committee of the Chinese Foreign Ministry; President, Institute of International and Strategic Studies, Peking University 
PRESIDENT'S COUNCIL

A distinguished group of individual and corporate donors providing essential support and expertise to Crisis Group.

\section{CORPORATE}

BP

Shearman \& Sterling LLP

Statoil (U.K.) Ltd.

White \& Case LLP
INDIVIDUAL

(5) Anonymous Stephen Robert

Scott Bessent Luděk Sekyra

David Brown \& Erika Franke Alexander Soros

Herman De Bode lan R. Taylor

\section{INTERNATIONAL ADVISORY COUNCIL}

Individual and corporate supporters who play a key role in Crisis Group's efforts to prevent deadly conflict.

\section{CORPORATE}

Anonymous

APCO Worldwide Inc.

Atlas Copco AB

Chevron

Edelman UK

Eni

HSBC Holdings PIc

MetLife

Noble Energy

RBC Capital Markets

Shell

INDIVIDUAL
(3) Anonymous
Mark Bergman
Stanley Bergman \& Edward
Bergman
David \& Katherine Bradley
Eric Christiansen
Sam Englebardt
The Edelman Family Foundation
Seth \& Jane Ginns
Ronald Glickman
David Harding
Geoffrey R. Hoguet \&
Ana Luisa Ponti
Geoffrey Hsu
David Jannetti

\author{
Faisel Khan \\ Cleopatra Kitti \\ Michael \& Jackie Lambert \\ Samantha Lasry \\ Leslie Lishon \\ Malcolm Hewitt Wiener \\ Foundation \\ The New York Community Trust - \\ Lise Strickler \& Mark Gallogly \\ Charitable Fund \\ The Nommontu Foundation \\ Brian Paes-Braga \\ Kerry Propper \\ Duco Sickinghe \\ Nina K. Solarz \\ Clayton E. Swisher \\ Enzo Viscusi
}

AMBASSADOR COUNCIL

Rising stars from diverse fields who contribute their talents and expertise to support Crisis Group's mission.

$\begin{array}{lll}\text { Amy Benziger } & \text { Lindsay Iversen } & \text { Nidhi Sinha } \\ \text { Tripp Callan } & \text { Azim Jamal } & \text { Chloe Squires } \\ \text { Kivanc Cubukcu } & \text { Arohi Jain } & \text { Leeanne Su } \\ \text { Matthew Devlin } & \text { Christopher Louney } & \text { Bobbi Thomason } \\ \text { Victoria Ergolavou } & \text { Matthew Magenheim } & \text { AJ Twombly } \\ \text { Noa Gafni } & \text { Madison Malloch-Brown } & \text { Dillon Twombly } \\ \text { Christina Bache } & \text { Megan McGill } & \text { Annie Verderosa } \\ \text { Lynda Hammes } & \text { Hamesh Mehta } & \text { Zachary Watling } \\ \text { Jason Hesse } & \text { Tara Opalinski } & \text { Grant Webster } \\ \text { Dalí ten Hove } & \text { Perfecto Sanchez } & \end{array}$

\section{SENIOR ADVISERS}

Former Board Members who maintain an association with Crisis Group, and whose advice and support are called on (to the extent consistent with any other office they may be holding at the time).

Martti Ahtisaari

Chairman Emeritus

\section{George Mitchell}

Chairman Emeritus

Gareth Evans

President Emeritus

Kenneth Adelman

Adnan Abu-Odeh

HRH Prince Turki al-Faisal

Óscar Arias

Ersin Arıoğlu

Richard Armitage

Diego Arria

Zainab Bangura

Shlomo Ben-Ami

Christoph Bertram

Alan Blinken

Lakhdar Brahimi
Kim Campbell
Jorge Castañeda
Naresh Chandra
Eugene Chien
Joaquim Alberto Chissano
Victor Chu
Mong Joon Chung
Pat Cox
Gianfranco Dell'Alba
Jacques Delors
Alain Destexhe
Mou-Shih Ding
Uffe Ellemann-Jensen
Gernot Erler
Marika Fahlén
Stanley Fischer
Carla Hills

Swanee Hunt

Aleksander Kwasniewski

Todung Mulya Lubis

Allan J. MacEachen

Graça Machel

Jessica T. Mathews

Barbara McDougall

Matthew McHugh

Miklós Németh

Christine Ockrent

Timothy Ong

Olara Otunnu

Lord (Christopher) Patten

Victor Pinchuk

Surin Pitsuwan

Fidel V. Ramos 